\title{
A POTENTIAL THEOLOGICAL PEDAGOGY FOR RECONSTRUCTING LIFE-GIVING MASCULINITIES IN AFRICAN CONTEXT:
THE CASE OF THE PILOT PROGRAMME ON GENDER, RELIGION AND HEALTH ${ }^{1}$

\author{
Chammah J Kaunda ${ }^{2}$ \\ School of Religion, Philosophy and Classics \\ University of KwaZulu-Natal
}

\begin{abstract}
In this article I claim that the theological pedagogy of the Pilot Programme on Gender, Health and Religion (Theology), has the promise for creating a potential life-giving theology of masculinities within the African context. To achieve this, I have analysed the interviews that were conducted for the Church of Sweden on the eight male postgraduate students in the Pilot Programme about the effectiveness of such an approach. The interviews highlighted that the Pilot model of theological education at UKZN enabled students to search for alternative ways of expressing their masculinities. I have argued that this theological pedagogy is not about changing the students' behaviour but enabling them to reflect on their formative cultural and theological experiences by putting incentives in place to empower them to hold themselves accountable to issues of gender justice and wholeness.
\end{abstract}

Key Words: Theological Pedagogy; Male Postgraduate Students; Pilot Programme; Culture; Masculinities; Critical Consciousness; Gender Justice and Wholeness

\section{Introduction}

The Church in Africa has been deeply implicated in promoting life-denying and dangerous theologies of masculinity which have contributed to social illnesses on the continent. Ezra Chitando, one of the most notable proponents of African masculinities has called for alternatives, arguing that Christianity "is a major force in the construction of masculinities across Africa..." Like all religious traditions, one critical aspect of a Christian world-view is the prescription of moral-ethical principles which govern and guide the beliefs and the moral action of its adherents by shaping and influencing their social relations, selfconception and health-related variables. The domain of the Church is never neutral but operates as a sub-culture and social structure of personal identity formation. Unfortunately,

This article is the result of reflection on interviews conducted for the Church of Sweden on monitoring and evaluation of the progress of the Pilot programme.

2 Chammah J Kaunda (PhD) is from Zambia. He is currently a postdoctoral Fellow in the School of Religion, Philosophy and Classics, University of KwaZulu-Natal. His research interests are: African Theology with a special focus on African Pentecostal Theologies, African Initiated Churches, Curriculum Design and Reform and Theological Education Ecumenical Theology and Systematic Theology.

3 Ezra Chitando, "Religion and Masculinities in Africa: its impact on HIV and gender based violence," 91-10, p.4. http://academic.sun.ac.za/teologie/netact/genderequality. [04 Oct. 13]. 
many churches in Africa remain beholden to self-conception as the mouthpiece of God entrusted with a message immune to being questioned. This theological assumption renders some churches generally blind to gender issues. This attitude should be understood from the background of the kind of scholarship which African Christianity inherited from European missionaries and which was perpetuated uncritically by African male theologians who did not include the experiences of women in their theologies of inculturation. ${ }^{4}$

Although the Church cannot be blamed entirely for masculinity malignancies in Africa, it has nevertheless contributed immensely to the perpetuation of dangerous masculinities that were inherent in some African cultures before the introduction of Christianity. ${ }^{5}$ Currently, African theologians (both male and female) have realised that the Church has entered into unholy union with African culture which is life-denying to women and children. It has been argued that the Church's access to God authenticates its definition of masculinities as sanctioned by God and therefore, is beyond questioning. Consequently, the adherents are ostracized from recognizing the dangerous traits wrapped around the dominant masculinity gospel of the Church. Adriaan van Klinken observes that little or no attention has been paid to the effects of such ecclesial articulation of masculinity on men as gendered beings. He adds that even "in the study of men and masculinities in Africa, on the other hand, neither religion in general nor born-again Christianity in particular are taken into account as relevant factors in the construction of masculinities." ${ }^{\prime 6}$ Indeed, many Church members in Africa seem to be trapped in the dominant gender discourse where there is no possibility of escaping social nepotism brought about by the Church's discourse on masculinity.

In this context, Ezra Chitando and Sophia Chirongoma have called upon the Church in Africa to "...develop masculinities that promote health and well-being for all." Elsewhere, Chitando has summoned the African churches "to rethink their mission towards men." $\mathrm{He}$ questions whether there are concrete ways in which the African churches can challenge "conventional forms of masculinity. How can hegemonic masculinities be deconstructed among Christian youth and men?" In another place Chitando had further questioned the value or the benefit of recognising how dangerous masculinities have contributed to maternal and infant mortality, and then failed to embark on practical strategies to construct

4 Chitando, "Religion and Masculinities in Africa..." p.4; Isabel Apawo Phiri, "Doing Theology in Community: The case of African women theologians in the 1990s," Journal of Theology for Southern Africa, 99 (November, 1997), 68-76; Nyambura Jane Njoroge, "The Missing Voice: African Women Doing Theology," Journal of Theology for Southern Africa, 99 (November, 1997:77-83).

5 For example, women among the Bemba people of Zambia, a traditionally matriarchal society with gender balanced concept of God as Mayo-Tata (Mother-Father) were stripped of their status of leaders by the Roman Catholic Church which introduced the patriarchal system in society. See: Chammah J Kaunda, "Reclaiming the Feminine Image of God in Lesa: Implications for Bemba Christian Women at the Evangel Assembly of God Church in the Post-missionary Era," Journal of Constructive Theology, 16/1 (July 2010:5-29); Hugo Hinfelaar, Bemba-speaking Women of Zambia in a Century of Religious Change (1892-1992), New York, NY: Brill, 1994.

6 Adriaan S van Klinken, "Men in the remaking: Conversion narratives and born-again masculinity in Zambia," Journal of Religion in Africa, 42/3 (2012:215).

7 Ezra Chitando and Sophie Chirongoma, "Introduction: On the Title" in Redemptive Masculinities: Men, HIV and Religion, Ezra Chitando and Sophie Chirongoma (eds.), Geneva: WCC Publication (2012:1).

8 Ezra Chitando, Acting in Hope; African Churches and HIV/AIDS 2, Geneva: WCC Publication (2007:40).

9 Chitando, Acting in Hope African Churches and HIV/AIDS 2, p. 40-41. 
alternatives. ${ }^{10}$ This article, then, is an attempt to suggest one practical strategy in the quest toward constructing alternative masculinities in Africa.

In this article I claim that through the Pilot Programme on Gender, Health and Religion (Theology) (hereafter, the Pilot) based on the School of Religion, Philosophy and Classics (hereafter, SRPC) of the University of KwaZulu-Natal (hereafter, UKZN) there is a possibility for creating a potential African theological pedagogy for reconstructing life-giving masculinities in an African context. In the successive sections I have elaborated a specific deconstructive approach which was employed in the classroom. I have analysed the interviews that were conducted for the Church of Sweden (hereafter, CoS) with the eight male Master of Theology (MTh) students in the Pilot about the effectiveness of such an approach (I return to this point below). The aim of this article, therefore, is to attempt to contribute to an on-going search for an effective way of transforming masculinities in Africa as a dynamic category. Secondly, it seeks to open up a space for developing a creative approach to the theological classroom as a site of struggle situated at the very centre of religio-cultural and political-economic conflicts, tensions, and compromises that seek to legitimate and covertly perpetuate hegemonic masculinities. Teaching in such a context is a subversive exercise; or rather, a transgression against social values, which requires adopting critical feminist pedagogies with conscious and clear intention to aid student transformation within such an educational environment. Therefore, I count it not only as a privilege to be part of the Pilot but also exciting and renewing academic adventure. Before I give a brief background to the Pilot and what it is about, I wish to revisit the emergence of the African theology of masculinity.

\section{Inviting Men to the Roundtable: Emergence of African Theology of Masculinity}

The study of masculinities is a recent phenomenon in African theological discourse. This does not mean that the discourse is new in the general scholarship in Africa. For instance, Robert Morrell, Professor at the School of Education at the UKZN in South Africa is one of the earliest scholars to engage with the subject coherently from a sociological perspective. ${ }^{11}$ However, the discourse remained male-centric or done exclusively by white South African men reflecting on African men. The shift within African theology as a critical scientific reflection on the Christian faith in the context of African religion and culture, history and contemporary experiences, came through the Circle of Concerned African Women's Theologians (hereafter, the Circle). The Circle officially introduced the epistemology during its fourth Pan-African Conference in Yaounde, Cameroon, in 2007. ${ }^{12}$ Before then both African men and women theologians had adequate exposure to academic thinking on the African masculinity discourse. For instance, African women theologians were primarily concerned with the critique of constructions of gender, gender norms and legitimising of male experiences within African theological discourse. The two decades of theologizing on gender justice in Africa, were culminated at this conference when African women theologians realised that "ifikala cimbwi tefikale nama ikata," [lit: the way the

\footnotetext{
10 Chitando, "Religion and Masculinities in Africa..." p. 9.

11 See, Chitando and Sophie Chirongoma, "Introduction", p. 5.

12 Isabel Apowa Phiri, "The Major Challenges for African Women Theologians in Theological Education (1989-2008)," International Review of Mission, 98/1 (April 2009:106).
} 
hyena sits is not the way a predator about to catch a prey sits]. ${ }^{13}$ This conference became a turning point in the progress of African the particular theological discourse as women recognized that women and men can only fully realise their humanity together and need each other in order to stop HIV in Africa. ${ }^{14}$ There was recognition that contemporary dominant masculinities in Africa are problematic in the context of HIV. In this way, HIV was perceived as an epistemic challenge demanding African theology to move beyond the discourse that unintentionally dichotomised theological thought between women and men and blinded them from realising that in the context of HIV there are no winners: both women and men are victims of certain types of behaviour from men that infringe on the rights and humanity of women. Chitando has argued that the HIV tsunami in Africa has followed patriarchal fault lines that were already in existence prior to the outbreak. ${ }^{15}$

In this case, the HIV epistemic became a locus for developing more sophisticated and critical theological methods of analysing how masculinities operate in African contexts and also of finding the specific ways in which these masculinities perpetuate gender injustice and inequality which contribute to the vulnerability of both women and men to HIV. This suggests that creating a gendered just and equitable society means transforming unequal gender power relationship patterns and patriarchy. It must be recognised that power and patriarchy are abstract concepts which are meaningless and can easily become obsolete in the absence of perpetrators. It has become clear that "not only women need to be empowered, but also men, in order to transform gender relations."

It is important to understand that while there is no unified definition of masculinity and the concept remains ambiguous, one thing is clear - the expression of what it means to be 'a man' is "constantly being protected and defended, ...constantly breaking down and being re-created. For gender activists this conceptualisation provides space for optimism because it acknowledges the possibility of intervening in the politics of masculinity to promote masculinities that are more peaceful and harmonious." ${ }^{\prime 17}$ In other words, what it means to be a man is a "social construction of male gender identities and of men's place in gender relations." 18 Masculinity in this sense can be considered as a constant social act or a way someone expresses and behaves in normal interaction with others. This means that masculinities are never static or monolithic but dynamic and in a constant state of flux. In other words, masculinities are "a set of socially constructed relationships which are produced and reproduced through people's actions." "I9 In Africa, masculinities are relationally and communally constructed not only in relation to women but the whole community. For Judith Butler, masculinities are "a set of repeated acts within a highly rigid regulatory frame

13 This Bemba proverb espouses that an animal about to catch the prey is always wrestling with creative methods of achieving the objective.

14 Phiri, "The Major Challenges for African Women Theologians...," p. 106.

15 Ezra Chitando, "'Religious ethics, HIV and AIDS and masculinities in southern Africa' in Persons in Community: African Ethics in a Global Culture, Ronald Nicolson (ed.), Scottsville: University of KwaZuluNatal Press (2008:50).

16 Adriaan van Klinken, "Transforming masculinities towards gender justice in an era of HIV and AIDS: Plotting the pathways," in Religion and HIV and AIDS: Charting the Terrains, Beverly Haddad, Scottsville: University of KwaZulu-Natal Press (2011:276).

17 Robert Morrell (ed.), Changing Men in Africa, Scottsville University of Natal Press, 2001.

18 Van Klinken, Transforming masculinities towards gender justice in an era of HIV and AIDS... p. 276.

19 Judith M Gerson and Kathy Peiss, "Boundaries, Negotiation, Consciousness: Reconceptualising Gender Relations,” Society for Study of Social Problems, 32/4 (April 1985:327). 

that congeal over time to produce the appearance of substance, of a natural sort of being." 20 Thus, the term masculinity is a verb - an action word. Masculinities as lived experiences are produced and reflect a particular cultural context but they also assimilate cross-cultural masculine traits through interaction, and this makes them adaptive and ever-changing according to the time and place. There are also certain forms of expression of masculinities that are obsolete and in need of transformation to be adequate in the ever-changing context. In other words, anything that is constructed can also be deconstructed. But sometimes traditional people would rather protect their own interests at the expense of progress and end up living an outdated and contextually irrelevant lifestyle. The implication of this is that to create a patriarchy-free society, both the innocent and covetous beneficiaries of the system have to be transformed. Yet transformation cannot happen in a vacuum. In addition, writing about alternative masculinities, as important as it is, cannot initiate a process of transformation as not many Africans have access to written materials. ${ }^{21}$ Therefore, a deliberate and safe platform for dialogue with men has to be initiated in order to facilitate the creation of, and appropriation of alternative masculinities. One such safe platform was the Pilot Programme, as shall be seen below. In addition, many alternative propositions on masculinities have not given serious attention to overcoming the seemingly growing chasm between the Church and theological education in Africa. This raises a question: in what ways can alternative masculinities be developed in mutual relationship with the churches? This question is significant as many of the alternatives which have been proposed are chiselled by scholars outside the churches and only imposed onto churches. As a response to this challenge, the Pilot Programme was introduced at post-graduate level at UKZN

20 Judith Butler, Gender Trouble: Feminism and the subversion of identity, New York: Routledge (1990:33).

21 In the post-Yaounde conference, a number of African male theologians have responded favourably to the call for roundtable dialogue and the need for liberating masculinities and a number of books and articles have been published. There are many African male scholars who have entered into theological conversation and collaboration with the Circle on promoting more life-centred masculinities. See, Ezra Chitando, "A New Man for a New Era? Zimbabwean Pentecostalism, Masculinities and the HIV Epidemic," Missionalia 35/3 (2007:112-127); Ezra Chitando, "Challenging Masculinities: Religious Studies, Men and HIV in Africa," in Journal of Constructive Theology 14/1 (2008:55-69); Ezra Chitando, "Religion and Masculinities in Africa: An Opportunity in Africanization," Handbook for Theological Education in Africa, Isabel Phiri and Dietrich Werner (eds.), Pietermaritzburg: Cluster Publication (2013:662-670); Adriaan S Van Klinken, "Male Headship as Male Agency: An Alternative Understanding of a 'Patriarchal' African Pentecostal Discourse on Masculinity," in Religion and Gender 1/1 (2011:104-124); Adriaan S van Klinken, "Transforming Masculinities towards Gender Justice in an Era of HIV and AIDS: Plotting the Pathways," in Religion and HIV and AIDS: Charting the Terrain, Beverley Haddad (ed.), Scottsville: University of KwaZulu-Natal Press, pp. 275-296; Adriaan S van Klinken, 'Theology, Gender Ideology and Masculinity Politics: A Discussion on the Transformation of Masculinities as Envisioned by African theologians and a local Pentecostal Church', Journal of Theology in Southern Africa 138, (2010:2-18); Gerald O West, “The Contribution of Tamar's Story to the Construction," in Redemptive Masculinities: Men, HIV and Religion, Ezra Chitando and Sophia Chirongoma, (eds.), Geneva: WCC Publications (2010:73-192). I have included two prominent white scholars though they cannot be categorically classified as African theologians but because there have focused their research energy on masculinities in Africa. Thought it remains critical to understand the underlying interests or what such scholars are seeking as it seems they are exploiting African knowledge and attach intellectual property rights (IPR) to it but forgetting that there is also such a thing as resource or indigenous knowledge rights. The questions may be raised: is it noble for outsiders to come and teach the African how to behave as men? Could this not be considered as a colonial mentality that perceives African men as boys needing to be taught on how to behave as men by white men? What is a more life-giving way to dialogue with outsiders coming to do their research in Africa? It is seems to me that such scholars are gaining higher degrees, academic recognition and promotions by extracting free knowledge from the indigenous people who remain poor. Could it not be argued that they are contributing to underdeveloping of Africa by exploiting the little knowledge that escaped colonialism? In an information age, caution must be taken as knowledge exploitation is a new form of colonisation. 
within SRPC in mutual partnership of trust framework with CoS with financial grant from the Swedish International Development Co-operation Agency (SIDA). ${ }^{22}$ From inception, the Pilot has been tailored to stimulate students' critical thinking around issues of masculinity and equipping them for transformative engagement in local communities. ${ }^{23}$ In the next section I briefly give the background and what the Pilot is all about.

\section{Transforming the Transformers: An Arena for Reconstructing Masculinities in Africa}

The specific focus of the Pilot has been on sexual and reproductive health and rights (hereafter, SRHR) and gender-based violence (hereafter, GBV) and is modelled after the Philani model. The Philani is a mentor mothers' community health worker home visiting programme to improve maternal and infants' conditions in the surrounding townships of Cape Town in South Africa. The programme has strong connection with the grassroots as it is grounded in praxis. To begin with, the Mentor Mothers' model has been replicated in Swaziland and Ethiopia and added to this are two distinct programmes developed with an objective of strengthening the link between the Church and the community and theological education.

The second is the Church and Community leaders training, ${ }^{24}$ also introduced in Swaziland and Ethiopia. The aim is "strengthening the role of the church and local leadership as agents for change in matters related to SRHR and GBV." 25

The third is the Master programme which builds on the previous experiences emerging from a Master project on HIV and Theology and is piloted in the four universities in three countries, that is: University of KwaZulu-Natal (Pietermaritzburg) and University of Stellenbosch (Cape Town) in South Africa, Tumaini University Makumira (Arusha), Tanzania, and the Ethiopian Graduate School of Theology (Addis Ababa) in Ethiopia.

The main objective of the Pilot on Master on Gender, Health and Religion (Theology) has been to overcome the gulf between the Church and theological education by encouraging students to do their research with the Mentor Mothers and Church and Community leaders that in the process can "strengthen theological praxis and awareness" on the interconnectedness of gender, health and theology. ${ }^{26}$ Lena Furberg stresses that "the rationale behind this approach is that exchange of knowledge and ideas, collaboration and reciprocity [among] the parts [will] create an added value that may contribute to an improved maternal and child health.,27

To achieve this, the Master on Gender, Health and Religion-UKZN has entered into critical partnership with Mentor Mothers and Church and Community leaders' programmes in Swaziland. Seminars and workshops have been intentionally and consciously organised to facilitate students' engagement with Mentor Mothers and Church and Community

\footnotetext{
22 Lena Furberg, “"The Bible does not want to see Children Dying': A Baseline and Monitoring Study of the Pilot Programme on Health, Gender and Theology," August 2013:3.

23 UKZN, "Gender and Religion Programme: School of Religion, Philosophy and Classics," Brochure (2013).

24 The concept of 'training' is quite problematic as it carries the connotation of domesticating. Rather an alternative concept such as 'equipping' may be viable in African contexts where people have been crying for liberation.

25 Furberg, "“The Bible does not want to see Children Dying...” 3.

26 "Logical Framework for the Pilot Program HGT- Master Component," 2013.

27 Furberg, "'The Bible does not want to see Children Dying..." 3.
} 
leaders on various issues related to intersectionality of gender, health and theology and masculinities has been one of the key concepts that have been discussed. It is perceived that through such engagements and collaboration, ideas being developed in theological education might filter through to the grassroots and promote life-affirming masculinities as the majority of Church and Community leaders are still men. In this way, this collaboration has been also a way of searching for possible alternative masculinities emerging in contemporary African society.

At UKZN the Pilot has aimed at nurturing "critical consciousness, on-going selfreflection and self-critiques," in order to deepen students" "understanding of masculinities, patriarchy, gendered power relations and their links with other forces of oppression and political, socio-economic, cultural, and religious structures and systems." ${ }^{28}$ The academic year of the programme started in February 2013 and ended in December 2013. It was a fulltime coursework and research programme spreading over two semesters as follows:

In the first semester, students took two core modules: the first, which was the most critical in the programme, carried a seminar approach which was facilitated by scholars from various disciplines to emphasise the interdisciplinary nature of the programme. Attention was given to how both African and western scholarship can respond to the impact of religion on the health and well-being of humanity. The core objective of the module was to discuss methodological, theoretical and theological frameworks of gender and feminist theologies in both Africa and the globe. ${ }^{29}$ The second was on research proposal writing which was passed after the proposal had been accepted by the Higher Degrees Committee.

Of the second semester modules the first was compulsory and focused on "Issues of Masculinity and Gender". The second module was an elective which gave students liberty to choose any course which was related to their specific research interest. In this same semester students were expected to submit a twenty-five thousand words dissertation to crown the academic year. ${ }^{30}$

These courses were formulated with a vision to promoting gender justice and social wholeness for all, which was seen to be achieved through personal transformation of social transformers. This was in line with African women theologians' perspective that the classroom is an arena of gender activism and transformation. Thus, through interdisciplinary and deliberate focus on masculinities, the students were being invited to the roundtable of dialogue to reflect on themselves as either innocent or covetous beneficiaries of life-denying patriarchal benefits.

Designed within theological education for transformation and problem-posing paradigms, the courses were concerned for the content of what to teach and the process of how to teach it. This vision was significant “...in promoting a particular ideological perspective in the classroom and that is a step in opening up possibilities for students to consider the effects and workings of dominant discourses in their own lives." 31 The classes were

28 Undarya Tumursukh et al., "Transforming Masculinities towards Gender Justice: Foundational Knowledge for Action," Regional Learning Community for East and Southeast Asia (RLC) (2013:3-4).

www.partners4prevention.org/sites/default/files/.../rlc. [09 Oct. 13].

29 Gender and Religion Course Outline, "Gender and Religion (2013 Emphasis - Gender Religion and Health)," College of Humanities: School of Religion Philosophy and Classics, UKZN, 2013.

30 Seven students out of eleven completed both the coursework and submitted their dissertations before the end of 2013. Four of them are remaining with only the dissertation and are expected to submit before the end of June 2014.

31 Wayne Martino, "Deconstructing Masculinity in the English Classroom: A site for reconstituting gendered subjectivity," Gender and Education, 7/2 (1995:212). 
structured as seminars to help students think on their subjectivity and the cultural experiences that formed them. The intention was to position the students to engage critically with various texts, to enable them "to question, challenge and react upon their own positioning" 32 as beneficiaries of patriarchy. The aim of such an approach, as Wayne Martino argues "is not to enforce attitudinal change, but to make available a space for students to consider other possibilities for making meaning and to consider other gendered positions outside of a phallocentric symbolic order." This demanded creating an environment where students could be challenged but not threatened - giving them an ecumenical safe space to think critically without being threatened by the official positions of their church affiliations.

Thus, the Pilot at UKZN became a safe space for students and lecturers from diverse backgrounds to engage in mutual ecumenical-transcultural dialogue in order to construct alternative forms of masculinities to promote equality in gender relations. I now turn to the method utilised for the interviews.

\section{Setting the Scene: Data and Methods of this Study}

The aim of this article is to develop a possible theological pedagogy for constructing lifegiving masculinities in Africa that can respond appropriately and effectively to issues of maternal and infant mortality. Therefore, the interpretive and deconstructive analytical method was considered feasible in making sense of the data which was gathered for the $\mathrm{CoS}$ on eight male students in the Pilot programme at UKZN. ${ }^{33}$ This data was initially generated for the purpose of monitoring and evaluating the progress of the project for the $\mathrm{CoS}$. The author as third part chose to reflect on this data in order to develop a possible framework for reconstructing life-giving masculinities in African contexts. The approach adapted for the method can be classified as third part qualitative analysis of the interview. In this approach, the author did not do the interviews for his/her personal research, and no ethical clearance was required as it had been granted to the original interviewers - that is, the CoS. Data was gathered through in-depth interviews with eight students from seven different countries in Africa of various ages, with the oldest having been born in 1962 and youngest in 1983. They come from diverse Christian traditions. Six of them are married and three are single. The interviews were conducted over a period of two weeks in the last part of August and the first week of September 2013. The interviews were audio-recorded after asking for permission from each interviewee. The approximate time devoted to interview protocol was 45 minutes per person. The audio-recorded interviews were then transcribed. The interviews carried a narrative approach where the participant was asked to narrate his experiences growing up as a man in a particular religio-cultural context. This approach is significant as it opens a religio-cultural space for personal introspection, interrogation and new ways of knowing freed from the dictates of cultural and Church configurations of maleness. It is an invitation to criticise dominant expressions of masculinity and resurfaces the need for constructing alternatives. In this sense, telling one's own story can be perceived as an act of liberation and entry into freedom. In the interest of discretion, the actual names of respondents are not used. A number of themes emerged from the interview but for the purpose of this article, I would like to look at two critical themes as following:

\footnotetext{
32 Martino, "Deconstructing Masculinity in the English Classroom...," p. 212.

33 There are eleven students in this programme, three females and eight males. All the males were interviewed.
} 
From Socialization to Rational Choices:

\section{Evolving a Theology of Life-giving Masculinities}

The data indicated that before coming to the Pilot, most of these students had no opportunity to reflect on their gender subjectivity and felt that they had been blinded through Church teachings and practices, cultural socialisation and a desire to remain loyal to their kinship. It was clear that the Pilot was a critical site of deconstructing and rethinking subjectivity as students reflected introspectively and theologically on the experiences that had shaped them as men within patriarchal institutions, material and economic social order. Often, these choices are based on preconceived ideas and information gleaned from personal experience, group dynamics and observed behaviour of players within the field. This knowledge can and does inform practice that can reproduce or transform inequality. Students feel that lack of consideration for the humanity of women by men has contributed to the social upheaval and bleakness in Africa. For instance, one student lamented that:

I was separated from my mother at an early age so that I could be trained to become a man. There was no opportunity to be close to women who were perceived to have a lower status or be inferior to men. The man was expected to assume superiority in the family, church and at every level of society. So I was trained to act in a particular way as a man unintentionally and unconsciously. That's why it's not easy to detect that one is oppressing a woman or even when women know that they are being oppressed unless there is critical education in such areas. Our society is dying because of bad masculinities. They are like viper venom in the blood stream of our society life. ${ }^{34}$

These actions are supported and affirmed by women, as a natural way for the men to act. For instance:

It is emphasised that the wife should kneel when giving something to the husband. If she doesn't kneel, the husband has a cultural right to beat her in order to subject her to the cultural norms and avoid embarrassment that could occur from the wife's disrespect. Or the wife has no right to refuse her husband sex - if she does, he can divorce her and she will embarrass not only herself but the respectable women of the community who are stripped naked for her to know what marriage is all about (premarital counselling). For that she may be ostracised as an uncultured woman. ${ }^{35}$

These are some of the cultural dynamics that surfaced as these students reflected on their cultural norms and values that give ontological value to the notion that through the process of maturation men become more superior to women and children. Through theological and dialectical reflection on their social and local church context, students begin to rethink their role as men in their church and society. In a way, theological education is touching the core of the ideology and toxic theologies that created the students as men as innocent and unconscious oppressors. This can lead the students to begin consciously to challenge and deconstruct those masculinities which were perceived as "death in the bloodstream of

34 Student \# 6, Interview with Chammah J Kaunda, 02 September 2013.

35 Student \# 6, Interview with Chammah J Kaunda, 02 September 2013.

In some African cultures, during premarital counselling, the respectable counsellors who are considered as custodians of tradition strip naked to the young bride in order to show her how to perform the sexual dance in the bedroom. See also Mutale M. Kaunda, "A Search for a Life-Giving Marriage: The Imbusa Initiation Rite as a Space for Constructing Wellbeing among Married Bemba Women of Zambia," Unpublished MTh. Diss., University of KwaZulu-Natal, Pietermaritzburg, (2013). 
society. $" 36$ The students were unanimous that upholding certain forms of masculinities is dealing in death. For instance, one student \#4 lamented:

We used to think that God has put that order that women should be dominated but I was re-educated about the view of God for humanity. And what also really made me feel a bit sinful is the concept of dehumanization, that when women are oppressed there is dehumanization, we treat them as less than humans. ${ }^{37}$

What seems clear in the statement is that the student is awakened from theological deception and realises that existing power relations are neither immutable nor sanctioned by God but socially constructed. This student further argued that "education is the key" to enable men realise that they have a free moral choice to redefine themselves as men. For other students, until they engaged on issues of gender in the classroom, their Christian perspectives, cultural beliefs and practices had colonised or trapped their self-conceptualization and not given them any options to look for alternative expressions of their masculinities. Student \#2 remembers:

I was in the middle, but my sisters because they were females, were forced to wash my clothes and they were forced to cook, they were doing everything for me because I was a male. I can still remember my mother saying 'this person is in charge of you.' We have never grown up in a situation where my sisters and I were on the same level. It has been like my mother indoctrinated them to see me as... high. ${ }^{38}$

Another student \#3 narrates:

...even though we are in a matrilineal society, this doesn't necessarily mean to say it will give more equality to women. Even in the matriarchal society you find that patriarchy has come in, in which everything is associated with the man. The concept of [patriarchy] in the matrilineal society is very strong. There might be no much difference, especially when it comes to the public life. In most cases it is always men who are leading. ${ }^{39}$

Student \#1 reveals:

In my culture women cannot make decisions, a woman can't make a concrete decision, cannot do anything on her own. They just come in not actually to give the real answer to the [problem], but she may come like something added but not an essential part, not someone important... It's not the girl who decides to get married, it's the parents. That one alone hampers the health of a girl. Because sometimes the man to whom the parents would decide to marry her is older than the girl or this man is a polygamist, is from a polygamist family, or sometimes a divorcee. So because the parents have accepted then this girl has no choice.... when a man sees a woman he sees a sex object, when a man sees a woman she sees an object of exploitation, when a man sees a woman he sees a promiscuous object, and when any man sees a woman, she is not a human being, but he sees something that can be exploited. ${ }^{40}$

In these cultural settings, there are clearly-defined moral ethical imperatives that constitute what it means to be a real man. There seems to be fixed dos and don'ts that define a man. Through cultural socialisation, men have been given a level of qualitative superiority to

\footnotetext{
36 Student \# 4, Interview with Chammah J Kaunda, 02 September 2013.

37 Student \# 4, Interview with Chammah J Kaunda, 02 September 2013.

38 Student \# 2, Interview with Chammah J Kaunda, 04 September 2013.

39 Student \# 3, Interview with Chammah J Kaunda, 03 September 2013.

40 Student \#1, Interview with Chammah J Kaunda, 30 August 2013.
} 
their female counterparts by virtue of being males. It is impossible to decolonise the mind from such socialisation as they are unconscious of the consequences of their masculinities on women and children. They have to be awakened to critical consciousness of the oppressive nature of certain cultural beliefs and practices to women and children. Thus, critical consciousness has potential to be a powerful strategy not only to enable men to understand social forces and the dynamics of oppression against women and children, but to give them an agency as agents of transformation in their communities. This theological pedagogy acts as therapeutic process in which men find it safe to begin to discuss openly their hidden assumptions about women as can be seen above. This is a process of selfactualisation that promotes the student's well-being. In other words, it helps men reexperience themselves as perpetrators of patriarchy through reflection on the subject in the classroom. The deja $v u$ nature of the experience can enable the students to begin to seek other ways of being a man. It helps them to vent their fears, masculinity stress and traumas of overburdening themselves with an insatiable desire to prove to the world that they are men. Certain African cultural practices and beliefs put a lot of men under enormous stress and pressure to prove themselves in society as men. There is a need for an empirical research on the experiences Africa men who fail to prove their manhood to their society. For example, student \#5 regrets:

As a man, there was a time whereby I really doubted my manhood. I doubted it because you cannot now stand in the public and say 'I am a good man' because of what our fellow men are doing out there, negative things. ${ }^{41}$

The way these students are reflecting on their personal experiences is almost like scales had fallen from their eyes as they seemed to realise that men have been socialised into a death dealing lifestyle. Hence, these men were challenging certain expressions of their masculinities by emphasising the danger of uncritical assimilation of culture and uncritical interpretation of Scriptures as loci for making personal choices and key reference points for the meaning of 'real man'. The significance of helping the students to reflect on their personal subjectivity lies in the fact that knowledge is rooted in experiences which shape human values and has a consequence on how human beings know, as well as how they use that knowledge. ${ }^{42}$ Students have to know that there is no such a thing as neutral knowledge but all knowledge has political mandate hence the need to reflect critically on it in order to construct theologies of life-giving masculinities.

\section{Rethinking and Relearning 'Manhood': Reconstructing a Gendered Subjectivity}

It is evident that through the process of conscientization, students are struggling to understand what really is wrong with men. Yet because of the non-threatening environment that was created in the classroom, these students seem to have gone through the process of reconfiguring themselves in the context of gender justice as they are given a chance to reflect on the experiences from different perspectives. They are developing alternative ways of thinking to aid their new action, testing what they have learned in new and more exciting ways. The result is formulating another more gendered experience at a more complex and

\footnotetext{
41 Student \# 5, Interview with Chammah J Kaunda, 04 September 2013.

42 Bell H\hooks, Teaching to Transgress: Education as the Practice of Freedom, New York: Routlege (1994:185).
} 
gender-sensitive level. This is evident in the phrases students used in describing their personal experiences in the Pilot. Student \#6 reveals that:

The programme has been an eye-opener and enabled me to deconstruct my perception of women as subhuman ...I'm being transformed. ${ }^{43}$

In a similar way student \#4 highlighted how the consciousness-raising nature of the programme created a critical platform for transformation of masculinities through critical search for alternatives. He narrates:

I have really been conscientized and maybe educated in that way, not only from my ... culture, but from my own religious understanding as well. I'm personally transformed in a way so that now I perceive myself differently...Because I come from a background where these issues are still problematic... So I'm thinking it's a key issue for ministers, especially gospel ministers to be able to speak about these things to the pews, speak about these things in the church. But the big transformation was, I felt that maybe I had had wrong teaching from the onset because I thought I was weak by doing gender but now really I'm seeing it's actually an opportunity to serve and to go back there. And personally even the way I relate to my wife, my family, my sisters, it has changed completely. Now, I'm seeing the value of the next person to me regardless of sex. ${ }^{44}$

Student \#7 explains his perception of what is taking place in the classroom as a process of being de-educated and re-educated to become a life-giving man. He stresses:

...I'm being de-educated about my cultural understanding of the position of women in the community and being re-educated about the understanding of women in community, the position of women in community. ${ }^{45}$

Another student (\#2) believes that being in the classroom for such a kind of a process has been a process of transformation.

Myself I have seen transformation. I'm very conservative, but then I have seen myself transforming in terms of discussion and gaining a lot out of looking at women as copartners... ${ }^{46}$

For another student (\#3), the Pilot has transformed his social life included his home life as a father.

I think for me, doing this programme, the gender programme has actually enabled me to see the inequalities that happen in my culture as well, both in the field of religion and also field of culture, cultural aspects as well. It has enabled me especially knowing some of the concepts, the gender concepts and I've come to appreciate how difficult it is for women in my society to attend their or to achieve in all dimensions because I see that the society - there are so many obstacles for women to achieve their goals as compared to men...Before coming to this programme, I was thinking maybe this is the norm, that it is just the way things are, this is the way things should be. But the programme has enabled me to say that 'No!' there is an alternative to how things could be in as far as the relationship between men and women is concerned in the life of the church and also the community....this transformation has also affected my way of doing things, even my role as the husband in the home. I found that I've been able now to guide my wife to pursue her higher education as well. Before then, it was like, okay, you can do it, but now it's 
like an informed choice...Secondly, on the biblical side, the course has also enabled me to look at some passages in the Bible and to be able to offer the gender lens. The Bible is becoming fresh. ${ }^{47}$

Student \#1 argues that after having such an experience there is no way of keeping silent anymore. He affirms:

It's now that I'm discovering that there is a need for gender equality, gender balance in my culture. I want to go and sensitize my community that it is important to educate both males and females. Because there is a potential even in women just the same way it applies to men. This course has transformed me in a way that I have to be realistic ... we are created with the same capacity to understand and to grasp issues. Because number one is, a child when it is born is not born with the intellect, the superiority of wisdom. It's like a blank container, without anything. So but now as the child grows up you start filling the container and at the end of the day it will get full. So a human being when he is born, men and women are all the same. But the environments we live in now start shaping us. So if women can be shaped just the same way we prepare a man, then we will be able to create a difference. Because like in my society when you are a male child you find that the father says, you have to be strong, you have to be aggressive, you know you are a man, don't behave like a woman. Already you are shaping the future of this child. ${ }^{48}$

Student \#8 explains how he re-encountered himself through the classroom:

I had quite interesting and transforming experiences. Basically, on the idea of gender itself, my previous view was that it has to do with women, and it's a pessimistic way of looking at things. These two beliefs changed. Because I no longer see it as something to do with women, I see it more to do with the relationship between men and women, in terms of power and distribution of power. Also I don't see it as a pessimistic approach to life, I see it more as an approach that is trying to seek balance. ${ }^{49}$

The mood of the above student discourses seems to disclose a mixture of lamentation and repentance for the contribution these men feel they have made to reinforce masculinities that are inconsiderate to the humanity of women. They want to be different and sensitise other men about the life-denying nature of certain cultural practices and religious belief systems. There is an evidence of self-criticism in the above statements suggesting a possibility for development of radical theological perspectives from which these students evaluated their cultural experiences and found them wanting. Bruce Thornton argues that "these generous and self-critical attitudes are a dividend of critical consciousness, the ability to step back from the passions and prejudices of the moment and look at events from a larger perspective that illuminates the common human condition, the way even an enemy suffers and grieves just as we do." ${ }^{.50}$ It is this deep relationship between self-consciousness and transformative theological education that reconstitutes gendered subjectivity which also allows a self-re-appropriation of men as life-givers. The responses above demonstrate that through the process of critical consciousness these students became willing to examine and challenge assumptions of masculinities "whose authority and legitimacy rest on the

47 Student \# 3, Interview with Chammah J Kaunda, 03 September 2013.

Student \#1, Interview with Chammah J Kaunda, 30 August 2013.

49 Student \# 8, Interview with Chammah J Kaunda, 04 September 2013.

50 Bruce Thornton, “Critical Consciousness and Liberal Education,” p.5, http://www.isi .org/books/content/379chap1.pdf. [15 Oct. 13]. 
unexamined acceptance of received dogma."51 They became eager to pursue the truth by questioning the unquestionable or cultural taboos for the sake of the health and wholeness of women and children. This is also a way of damage control to hostile theologies that have created masculinities with no regard for others' humanity.

By reflecting critically on their position as gendered subjects who have participated in and reinforced the oppression of women intentionally or unintentionally, men become theologically empowered to reclaim their agency as life-givers which was confiscated from them through cultural socialization and certain unsafe Church beliefs and practices. In a way, these students are challenging dominant theologies of masculinities within their culture and churches. Through this process they seem to be analysing their own positioning within such masculinities. It is important to note that a wrong biblical interpretation of what it means to be a man leads almost inevitably to certain behaviour that is destructive to the society. The students are also rejecting continuing being slaves of an ideology which benefits very little but demands their very life as a worthier sacrifice. In this way, they are taking a critical stance against cultural and theological traits that constructed them as men and searching for alternatives for reconfiguring themselves. Indeed, the Pilot has given them an opportunity and tools to develop patterns for reinterpreting and developing skills to enable them to act and to do, think and speak, listen and see in a life-giving manner. This new way of knowing themselves as men is as creative as the process they took to destroy life-denying theologies of masculinities to which they were once slaves. In the process of the Pilot further experiences and reflection led them to refine their mental patterns and to fine-tune and enhance newly acquired positive masculinity skills. This is based on the principle that people are what they believe or as Stephanie Lawler argues, who a person thinks is, and unconsciously accepts, in the process he/she becomes that person. ${ }^{52}$

Yet there is a possibility that some of these men might have said these things to impress the interviewer because of power dynamics and the funding attached to the programme. They may have just adapted but not transformed in anyway - which may be unfortunate. Such can be called camouflage masculinities which can easily envelop themselves within challenging discourses and develop a resistance shield against gender justice and equality. These masculinities are like aggressive mimicries that can adopt harmless characteristics seemingly affirming gender justice and equality just to avoid detection in order to achieve an almost free post-graduate theological education.

Nevertheless, one is hopeful that in the context of theological education for transformation the students are enabled to move from perceiving their perspectives as final and unchallenged to reflecting upon them in the light of new evidence, to thinking about them in different ways and embracing alternative ways of being. It is about raising theological consciousness of students that human beings are always becoming and they can choose the way they want to become. Through this theological pedagogy students can integrate the new learning and modify past experiences to fit the context of gender justice. There is a possibility of opening up a counter-domination space for dialogue with potential for reconstructing men as dynamic subjects who can keep on refiguring and re-configuring themselves in the process of ups and down as they learn to surrender themselves to lifegiving theologies of masculinities in the context of gender justice and social wholeness. The significance of this approach is that it can enable students to remain open to the possibility of new knowledge, other ways of being and alternative and positive ways of

51 Thornton, "Critical Consciousness and Liberal Education," p. 6

52 Stephanie Lawler, Identity: Sociological Perspectives, Cambridge: Polity Press (2008:59). 
expressing their masculinities. This suggests a new way of being in the classroom with others who are committed to the vision of a gender just and equitable society. The classroom becomes a safe space where one can reconnect to the root of the true human inside, rethinking and repenting of the past contribution to perpetuating of patriarchy, and envisioning a future free of gender bias - a just, humanised future.

\section{Conclusion}

The contemporary African horrors of rapid spread of HIV, maternal and infant mortality seem to be a result of uncritical acceptance of certain cultural beliefs and practices that have privileged men over and above women and children. In this kind of a context one cannot just offer education for its sake but as intentional and critical consciousness-raising education to enable students to thinking critically about the forms of masculinities dominant in their contexts and find viable ways of emancipating themselves from the enslaving chains of patriarchy - a selfish and monstrous system that has no regard for either the humanity or life of any individual in the community, including those who perpetuate it. Thus, to surmount theologies that promote life-denying masculinities - an offspring of patriarchy - the struggle will have to be waged at the level of how people think and express their ideas in action. This is a context in which engaged theological education can contribute to critical thinking to help students find their own freedom to make choices that place them in opposition to any system of "education or culture that would require them to be passive recipients of ways of knowing." 53

By beginning with a reflection on experiences of women in their cultural context, students can begin to analyse critically their role in reinforcing oppressive cultural practices and beliefs. At the same time, critical thinking enables them to think about themselves not as outsiders but as insiders who have contributed to the way things are in their society. By relating their own beliefs and practices to the wider knowledge, they can become conscientized and heed the current call for gender justice, equality and women's rights. Thus, they are able to analyse their theological perspectives, sociocultural beliefs and practices and ways of transforming the reality. In this kind of theological education, formulation of alternative expressions of masculinities is done by the students themselves as they create, imagine and invent new alternative life-giving ways of thinking theologically. Such a theological pedagogy creates a space for theologically deconstructing certain masculinities which are not productive to the society by creating possible safespaces for the reconstruction of life-giving theologies of masculinities. Thus, this theological pedagogy made students become more aware of the origins of their own behaviour codes and beliefs.

53 hooks, Teaching to transgress, p. 185. 


\section{BIBLIOGRAPHY}

Butler, Judith 1990. Gender Trouble: Feminism and the subversion of identity. New York: Routledge.

Chitando, Ezra and Sophie Chirongoma 2012. "Introduction: On the Title" in Ezra

Chitando and Sophie Chirongoma (eds.). Redemptive Masculinities: Men, HIV and

Religion. Geneva: WCC Publication, pp. 1-27.

2008. "'Religious ethics, HIV and AIDS and masculinities in southern Africa'

in Ronald Nicolson (ed.). Persons in Community: African Ethics in a Global

Culture. Scottsville: University of KwaZulu-Natal Press, pp. 45-63.

2007. "A New Man for a New Era? Zimbabwean Pentecostalism, Masculinities

and the HIV Epidemic," Missionalia, 35/3, pp. 112-127.

2008. "Challenging Masculinities: Religious Studies, Men and HIV in Africa,"

Journal of Constructive Theology, 14/1, pp. 55-69.

2013. "Religion and Masculinities in Africa: An Opportunity in

Africanization," Isabel Phiri and Dietrich Werner (eds.) Handbook for Theological

Education in Africa. Pietermaritzburg: Cluster Publication, pp. 662-670. 2007. Acting in Hope African Churches and HIV/AIDS 2. Geneva: WCC

Publication.

2013. "Religion and Masculinities in Africa: its impact on HIV and gender based violence," 1-10, http://academic.sun.ac.za /teologie /netact /gender equality. [04 Oct. 13].

Church of Sweden 2013. "Logical Framework for the Pilot Program HGT- Master Component."

Furberg, Lena 2013. “"The Bible does not want to see Children Dying': A Baseline and Monitoring Study of the Pilot Programme on Health, Gender and Theology." (August 2013:1-56).

Gender and Religion Course Outline 2013. "Gender and Religion (Emphasis - Gender Religion and Health)." College of Humanities: School of Religion, Philosophy and Classics, UKZN, 2013.

Gerson, Judith M and Kathy Peiss 1985. "Boundaries, Negotiation, Consciousness: Reconceptualising Gender Relations." Society for Study of Social Problems 32/4 pp. 317-331.

Hinfelaar, Hugo 1994. Bemba-speaking Women of Zambia in a Century of Religious Change (1892-1992). New York, NY: Brill.

Hooks, Bell 1994. Teaching to Transgress: Education as the Practice of Freedom. New York: Routledge.

Kaunda, Chammah J 2010. "Reclaiming the Feminine Image of God in Lesa: Implications for Bemba Christian Women at the Evangel Assembly of God Church in the Post-missionary Era." Journal of Constructive Theology, 16/1 (July), pp. 5-29.

Kaunda, Mutale M 2013. "A Search for a Life-Giving Marriage: The Imbusa Initiation Rite as a Space for Constructing Wellbeing among Married Bemba Women of Zambia," Unpublished MTh. Diss., University of KwaZulu-Natal, Pietermaritzburg.

Lawler, Stephanie 2008. Identity: Sociological Perspectives. Cambridge: Polity Press.

Martino, Wayne 1995. "Deconstructing Masculinity in the English Classroom: A site for reconstituting gendered subjectivity." Gender and Education, 7/2, pp. 205-220.

Morrell, Robert (ed.) 2001. Changing Men in Africa (Scottsville University of Natal Press. 
Njoroge, Nyambura J 1997. "The Missing Voice: African Women Doing Theology." Journal of Theology for Southern Africa, 99 (November), pp. 77-83.

Phiri, Isabel A 1997. "Doing Theology in Community: The case of African women theologians in the 1990s." Journal of Theology for Southern Africa, 99 (November) pp. 68-76.

.2009. "The Major Challenges for African Women Theologians in Theological Education (1989-2008).” International Review of Mission, 98/1 (April) pp.105-119. Student \# 1, Interview with Chammah J Kaunda, 30 August 2013.

Student \# 4, Interview with Chammah J Kaunda, 02 September 2013.

Student \# 6, Interview with Chammah J Kaunda, 02 September 2013.

Student \# 3, Interview with Chammah J Kaunda, 03 September 2013.

Student \# 2, Interview with Chammah J Kaunda, 04 September 2013.

Student \# 5, Interview with Chammah J Kaunda, 04 September 2013.

Student \# 8, Interview with Chammah J Kaunda, 04 September 2013.

Student \# 7, Interview with Chammah J Kaunda, 13 September 2013.

Thornton, Bruce 2013. "Critical Consciousness and Liberal Education," 1-11,

http://www.isi .org/books/content/379chap1.pdf. [15 Oct. 13].

Tumursukh, Undarya et al. 2013. "Transforming Masculinities towards Gender Justice:

Foundational Knowledge for Action," Regional Learning Community for East and

Southeast Asia (RLC), .www.partners

4prevention.org /sites/default/files/ [09 Oct. 13].

UKZN 2013, “Gender and Religion Programme: School of Religion, Philosophy and Classics," Brochure.

Van Klinken, Adriaan S 2010. “Theology, Gender Ideology and Masculinity Politics: A Discussion on the Transformation of Masculinities as Envisioned by African theologians and a local Pentecostal Church." Journal of Theology in Southern Africa 138, pp. 2-18.

2011. "Male Headship as Male Agency: An Alternative Understanding of a

'Patriarchal' African Pentecostal Discourse on Masculinity." Religion and Gender 1/1, pp. 104-124.

.2013. "Transforming Masculinities towards Gender Justice in an Era of HIV and AIDS: Plotting the Pathways," in Religion and HIV and AIDS: Charting the Terrain, Beverly Haddad (ed.), Scottsville: University of KwaZulu-Natal Press, pp. 275-296.

2012. "Men in the remaking: Conversion narratives and born-again masculinity

in Zambia." Journal of Religion in Africa, 42/3, pp. 215-239.

. 2011. "Transforming masculinities towards gender justice in an era of HIV and AIDS: Plotting the pathways," in Religion and HIV and AIDS: Charting the Terrains. Beverley Haddad (ed.). Scottsville: University of KwaZulu-Natal Press, pp. 275-296.

West, Gerald O 2010. "The Contribution of Tamar's Story to the Construction," in Ezra Chitando and Sophia Chirongoma, (eds.) Redemptive Masculinities: Men, HIV and Religion,. Geneva: WCC Publications, pp. 73-192. 